\title{
Rita Szaszkó (Hungary) \\ The Effects of the LLP Erasmus Mobility Programme on Cultural Biases and Affective Attitudes
}

\begin{abstract}
Summary: A pilot empirical investigation was carried out to gain insights into what impacts the Lifelong Learning Programme (LLP) Erasmus student mobility programme had on the participants' cultural biases, and their affective attitudes towards the target culture, in which the Erasmus study/internship took place. A further aim of this small scale study was to pilot the interview questions for a larger scale qualitative study. The six participants were selected by convenience sampling to complete a 24-open-ended-item interview schedule, which was analysed by protocol analysis. It was found that all of the Erasmus student respondents perceived that they became more open towards the world and other cultures. Next, they experienced false beliefs about the target culture to a minor extent. Furthermore, the students at the host Erasmus partner institution had certain but limited cultural information about Hungary and they mainly know about the capital. Also the participant Erasmus students gathered information about the target country and culture before commencing their studies or traineeship aboard. Finally, all of the respondents perceived that during their Erasmus programme their positive experiences abroad outnumbered the negative ones and they would be willing to return as tourists to their Erasmus target country some day. The data analysis also detected that the interview items can yield information to study Erasmus students' cultural biases and attitudes. However, an extension of the protocol with further cultural bias related items can be beneficial.
\end{abstract}

Резюме: Было проведено эмпирическое исследование в качестве пилотного исследования с целью получения более глубокого взгляда на то, какое воздействие имеет программ мобильности непрерывного обучения «Эразмус» на культурные предубеждения и аффективного поведения студентов в отношении культуры страны, в которой они реализуют эту программу. Другой целью этого небольшого исследования была попытка проведения опросного интервью для более обширного качественного исследования. Шесть участников были выбраны методом «нерепрезентативной выборки». Они должны были заполнить ряд, состоящий из 24 открытых вопросов, которые были оценены анализом протокола. Было выяснено, что у участников программы «Эразмус» было чувство, что они стали более открытыми для мира и других культур. Далее они сами поняли, что имели неверные представления о культуре, в которой они оказались. Кроме того, студенты уже имели некоторую информацию о Венгрии, в первую очередь, о столище. Венгерские студенты, принимающие участие в данном исследовании, перед своей учебной поездкой собрали информацию о стране и культуре своей цели. В конечном счете, у всех отвечающих было чувство, что у них было больше позитивных, чем негативных переживаний, и что они обязательно вернуться в эту страну в качестве туриста. Также анализ данных показал, что пункты интервью пригодны для того, чтобы будущие участники программы «Эразмус» смогли получить ценную информацию относительно свочх культурных предубеждений и позиций. Однако полезным было бы увеличение количества пунктов, которые касаются культурных предубеждений.

Zusammenfassung: Es wurde eine empirische Forschung als Pilotstudie durchgeführt, um einen tieferen Einblick zu bekommen, welche Wirkung das Erasmus-Mobilitätsprogramm des lebenslangen Lernens (LLP) auf kulturelle Vorurteile (cultural biases) und affektive Haltungen der studentischen Teilnehmer hinsichtliche der Zielkultur hat, also der Kultur des Landes, in dem die Studierenden dieses Programm durchführten. Ein weiteres Ziel dieser kleinen Studie war es, die Interview-Fragen für eine größere qualitative Forschung auszuprobieren. Die sechs Teilnehmer wurden mit einer 'convenience sampling' ausgewählt. Sie hatten die aus 24 offenen Fragen bestehende Fragenreihe auszufüllen, die mit einer Protokollanalyse (protocol analysis) ausgewertet wurden. Herausgefunden wurde, dass diese ERASMUSTeilnehmer das Gefühl hatten, dass sie offener für die Welt und andere Kulturen wurden. Weiterhin nahmen sie selbst falsche Vorstellungen von der Zielkultur wahr. Außerdem hatten die Studierenden in den Gastinstitutionen schon einige wenige Informationen über Ungarn, in erster Linie über die Hauptstadt. Die an dieser Studie teilnehmenden ungarischen Studierenden haben Informationen über das Zielland und die Zielkultur vor ihren Studienreisen gesammelt. Letztendlich hatten alle Antwortgeber das Gefühl, dass sie 
viel mehr positive als negative Erlebnisse hatten, und dass sie einmal als Tourist in ihr Erasmus-Land zurückkehren wollten. Die Datenanalyse hat auch gezeigt, dass die Interview-Items geeignet sind, wertvolle Informationen für künftige Erasmus-Studierende hinsichtlich ihrer kulturellen Vorurteile und Einstellungen zu vermitteln. Nützlich wäre allerdings eine Erweiterung der Items, die sich auf kulturelle Vorurteile beziehen.

\section{Aims and Research Questions}

Erasmus was a sub-programme of the LLP from 1987 to 2013 and its activities continue under the new Erasmus+ programme from 2014-2020. The LLP Erasmus higher education student mobility programme's principal aim was to offer equal chances of international academic experience and intercultural experiences regardless of the participating students' age, gender, social background or ethnic identity. To present, $80 \%$ of the applicants have travelled abroad for the first time and $60 \%$ of them are female. Throughout its more than 25-year history and with approximately 3 million students involved in it by 2013, the Erasmus programme's primary goal is to ensure equal educational standards in Europe. ${ }^{1}$ Accordingly, in order to be entitled to apply for an Erasmus study or internship programme, an applicant student has to meet the criteria of foreign language competence (levels B1/B2/C1/C2) ${ }^{2}$ in the target language and/or English as the lingua franca and perform an expected level of academic achievement (usually good/very good/excellent) at his/her home institution.

In the present research it is investigated how cultural biases are affected during Erasmus student mobility among students and how their affective attitudes change. Another aim of this investigation was to pilot the interview schedule for a larger scale interview study. Through this qualitative investigation the objective was to find answers to the research questions which are as follows:

1. What impacts does the LLP Erasmus student mobility programme have on the participant students' cultural biases?

2. What effects does Erasmus students' mobility have on the participants' affective attitudes?

3. To what extent can the pilot interview schedule elicit informative answers to the research questions?

In what follows, first the definition of the key concepts as well as a brief overview of the base and seminal theories of intergroup/intercultural contact research will be provided. Next, the six participants, the 24-item semi-structured interview schedule, the procedure of the data collection and finally, the results of the interview data protocol analysis will be presented.

1 Tempus Közalapítvány, Retrieved on 30 January 2013 from http://www.tpf.hu/pages/content/index.php?page_id=578, European Commission, Education and Training, Retrieved on 4 August 2014 from http://ec.europa.eu/education/tools/llp_en.htm

2 Council of Europe, Common European Framework of Reference for Languages: Learning, Teaching, Assessment (CEFR), Retrieved on 4 August 2014 from http://www.coe.int/t/dg4/linguistic/cadre1_en.asp 


\section{Theoretical Framework}

\section{Key concepts}

Initially, the cue words Erasmus study, Erasmus student placement, foreign Erasmus student, target culture, target language, cultural bias and affective attitude need to be defined in the present research context.

Erasmus study is a mobility programme for studying in Europe; that is university and college students, who meet the LLP Erasmus criteria, are entitled to spend a period of study between 3 months and 12 months at a host higher education institution, which holds an Erasmus University Charter. ${ }^{3}$ Higher education students are also enabled to apply for Erasmus student placement to do traineeship or internship between 3 months and 12 months at an organization or smaller business enterprise in the European context. ${ }^{4}$ Erasmus study and student placement may be combined with a maximum period of 24 months. In this research a foreign Erasmus student is defined as a nonHungarian student abroad (member of the target or any other non-Hungarian culture), which is the venue of the Hungarian student's mobility programme. In this paper target country and host country are regarded as synonyms meaning the foreign country, the destination where the participant Hungarian Erasmus student's mobility programme was done. Furthermore, the official language of the target country is referred to as the target language.

There are various approaches to the definition of cultural bias. The term 'bias' has a negative implication meaning prejudice and "a tendency to believe that some people, ideas, etc., are better than others" ${ }^{\prime \prime}$. Cultural bias can be conceptualized as contact with foreign cultures, which is affected by how a person perceives his own native culture and the members of another cultural group (Dick, Wagner and Pettigrew; 2004 Nemetz-Robinson, 1985). Furthermore, it must also be noted that:

Positive perceptions of other people are related to perceptual matches between what is anticipated and what is perceived, the positivity of traits perceived and the extent to similarity perceived. [...] negative perceptions and cross-cultural misunderstandings are related to perceptual mismatches and differences perceived. (Nemetz-Robinson, 1985, p. 71)

Nemetz-Robinson (1985) emphasised that cultural biases can be weakened by positive intercultural experiences and the lack of false beliefs about the target culture or/and members of the target culture. In a similar vein, negative impressions during intergroup contact and fossilized false beliefs can result in strong cultural biases in individuals. In the present research context the key construct of cultural bias is regarded as a concept with 'neutral' implications or more precisely, a concept which is constituted by the participants' positive/negative cultural assumptions, beliefs or false

3 European Commission, Education and Training. Retrieved on 30 January 2013 from http://ec.europa.eu/education/erasmus/study_en.htm

4 European Commission, Education and Training. Retrieved on 30 January 2013 from http://ec.europa.eu/education/erasmus/placement_en.htm

5 Merriam Webster on-line dictionary. Retrieved on 4 August, 2014 from http://www.merriamwebster.com/dictionary/bias 
beliefs as well as factual information that they have collected about the target language/culture/country and its people. The other key variable of this investigation is affective attitude, which is defined as a component of intercultural attitudes, which implies feelings and emotional reactions towards a country, culture or another ethnic group (Eller \& Abrams, 2006; Scott, 1966).

\section{Intercultural Contact Research}

The LLP Erasmus student mobility programme lends itself for various types of intercultural encounters within and outside the classroom. Therefore, what comes next is a brief summary of the evolution of the theory of intercultural contact research.

Social scientists Watson (1947) and Williams (1947) (Pettigrew, 1998) were the first to theorize about intergroup contact. However, investigations into intercultural encounters and their impacts on the participants are stemmed from Allport's seminal base Contact Hypothesis (1954), which remained unchallenged for a long period. It claimed that there were four optimal contact conditions capable of decreasing prejudice against foreigners, which are as follows: (1) equal status, (2) common goals, (3) cooperation not competition, and (4) support of authorities and institutions. Equal status is regarded as crucial in a context where two different cultural groups interact. However, Cohen (1982) and Cohen and Lotan (1995) pointed the perceived importance of equal status, which is experienced by the participants interacting in an intergroup encounter. Common goals shared by each group member are crucial to have positive, prejudice reducing outcomes. Furthermore, in order to achieve common goals intergroup cooperation (not competition) is necessary to establish positive attitudes and to decrease prejudice. It is emphasised that cooperation can be supported by educational institutions, for instance via bilingual or immersion educational programmes.

However, during the 1980s certain problems were detected regarding Allport's (1954) general model. First, Pettigrew $(1986,1998)$ and Stephan (1987) pointed at the fact that Allport's theory consisted of a long list of determining factors essential for a positive experience during intergroup contact. Secondly, the Contact Hypothesis was a model which failed to explain the constantly changing nature of intercultural contact effects. Also Allport's list of the necessary factors for intercultural encounters with a favourable outcome suggested a uniform nature of intergroup contact, which in fact is situation and subject specific. That is, every contact situation and participant interacting in an intercultural encounter can be regarded as different. All in all, Allport's theory highlighted when intergroup contact can result in positive attitude change; however, a proper amount of specific investigations into how and why these attitudes change were missing.

Pettigrew's reformulated contact theory (1998) involved the following essential elements: 1) participants' characteristics (individual differences), 2) situational factors (circumstances of encounter) and 3) societal factors (participants' social status). Furthermore, according to Pettigrew (1986, 1998), there were four processes that affected the nature of intergroup relationships: (1) learning about the outgroup, (2) changed behaviour (3) affective ties and (4) ingroup. Van Dick, Wagner and Pettirew's model (2004) focused on the perceived importance of a specific intercultural encounter and laid emphasis on the phenomenon that attitude formation depends on the beliefs of a particular individual.

Stephan's revised model of the Contact Hypothesis (1987) revealed that both the situation and person components were interacting with one another and were affected by societal factors 
regarding affect, cognition and behaviour. According to Scott (1966), the societal factors are the variables of intercultural attitudes. Affective attitude relates to feelings and emotional reactions towards a country and the members of it. Cognitive attitude refers to the size and wealth of a particular country. Finally, action or behaviour attitude implies to what extent an individual would be willing to provide help and be hospitable towards the members of a foreign culture.

The reasons of why and the modes of how intercultural encounters can facilitate positive intergroup relationships can be approached through the discussion of the significance of subjective perception of contact and the effects of cognitive biases. According to Nemetz-Robinson (1985), during intercultural contact cues (the perception of the other's physical appearance, behaviour, verbal characteristics, language, paralanguage and the context) and schemas (cognitive structures regarding a person and an event, through which information was interpreted) are influential. Nemetz-Robinson claimed that certain cognitive biases tend to lead to the negative perception of exposure to another culture or a member of another ethnic group. Furthermore, first impressions are created because of limited information and/or access to the target country.

Tajfel and Turner's social identity theory (1979), which claimed that people's social identities were shaped by their self concept, and a part of which was people's memberships in several groups. Tajfel and Turner regarded ingroup bias/ethnocentrism as an omnipresent characteristic of interethnic relationships. Furthermore, Tajfel and Turner maintained that motivational and cognitive processes were crucial to thoroughly understand the perception and behaviour of individual partaking in intergroup encounters (Brewer and Kramer, 1985).

\section{Method}

\section{Participants}

The participants were selected and recruited by purposive and convenience sampling (Dörnyei, 2007). The respondent six students took part in the LLP Erasmus student mobility programme in the academic years of 2011-12 and/or 2012-13 and attended the same higher education institution in Hungary. They obtained a Bachelor degree in one of the three fields which are: Adult Education, Computer Library and Lower-Primary-School Teaching. To meet the ethical criteria of research, the participants will be referred to by pseudo-names and the names of the host towns/cities will not be mentioned.

Table 1 Background details of the interviewed Erasmus students ( $N=6$ )

\begin{tabular}{lcccccc}
\hline Name & Specialization & $\begin{array}{c}\text { Years of } \\
\text { Erasmus } \\
\text { mobility }\end{array}$ & $\begin{array}{c}\text { Length of } \\
\text { Erasmus } \\
\text { mobility }\end{array}$ & $\begin{array}{c}\text { Type of } \\
\text { Erasmus } \\
\text { mobility }\end{array}$ & $\begin{array}{c}\text { Target } \\
\text { country }\end{array}$ & $\begin{array}{c}\text { Language of } \\
\text { communication }\end{array}$ \\
\hline Roland & CL & $2012-13$ & 7 months & internship & Romania & Hungarian \\
Dia & LPST & $2011-12$ & 6 months & study & Italy & English, Italian \\
Zoe & AE & $2011-12$ & 7 months & combined & Germany & German \\
Vera & CL & $2012-13$ & 10 months & study & Finland & English, Finnish
\end{tabular}




\begin{tabular}{lcccccc} 
Marian & AE & $2011-12$ & 9 months & combined & Italy & $\begin{array}{c}\text { Italian, German, } \\
\text { English } \\
\text { Nora }\end{array}$ \\
& LPST & $2011-12$ & 10 months & combined & Italy & English, Italian \\
\hline
\end{tabular}

Notes: AE=Adult Education (Andragogy), CL=Computer Library, LPST=Lower-Primary-SchoolTeaching

As Table 1 reveals all but one of the participants are female. Zoe and Marian specialized in Adult Education, Roland and Vera in Computer Library while Dia and Nora in Lower-Primary-School Teaching. These students took part in the LLP Erasmus student mobility programme during the period between 2011 and 2013 for different length of time. The longest duration of visits are Vera's nine-month study programme in Finland and Marian's ten-month combined programme of study and internship in Italy. Dia spent the shortest time, six months studying in Italy. Three students had a combined Erasmus programme while two of them had study only and one student internship only. Three students' destination was a reputed old historic university town in Italy, one travelled to a city in Finland, one of them to a city in Germany and one to a historic town in Romania. Only one of the participants did not have a working knowledge of English but German. Other foreign languages spoken by the participants are Italian (3) and Finnish (1).

\section{Semi-Structured Interview Schedule and Procedure}

The semi-structured interview protocol consists of seven questions to elicited some background information about the respondents followed by 17 open-ended items all formulated in the participants' native language, Hungarian.

Table 2 The variables of the semi-structured interview schedule

\section{Cultural biases}

Affective attitude

- Gathering information before travelling

- False beliefs about the target culture

- Cultural information about Hungary

- Positive perceptions

- Negative perceptions

- Overall impressions

The open-ended sections were constructed to yield information about the components of the two main constructs of this investigation: cultural bias, and affective attitude (Table 2). Cultural biases are rooted in looking at a foreign culture through standards characteristic of a person's own native culture (Dick, Wagner and Pettigrew 2004; Nemetz-Robinson, 1985). That is, lack of proper and efficient amount of information about a foreign culture can result in drawing false conclusions and in the fossilization of false beliefs about a particular foreign culture. Therefore, in the interview items certain possible sources of cultural misinterpretation were focused on. Furthermore, the 
questions were formulated to find out what information about Hungarian culture foreigners mentioned to the Hungarian Erasmus students during their mobility. The interview schedule was also designed to highlight the Hungarian Erasmus students' positive and negatives perceptions during their stay in their host countries. Concerning affective attitude, it is regarded as a fourcomponent construct involving attitudes towards the target language, culture, county and the members of the target culture (Scott, 1966).

The interview schedule was not piloted through one-to-one interview sessions; instead the participants were requested to send their detailed answers in writing. The interview-schedule was made and distributed in an electronic format as a Word-document attached to a cover e-mail. The filled in documents were returned via e-mail, too. The completion of the questionnaire items took 17 minutes on average and the procedure was carried out in January 2013. The qualitative data was analysed with protocol analysis using the technique of the categorization and colour-coding of the emerging patterns related to the components to the constructs of the research instrument. As the following phase of the piloting process, this interview protocol will be tested via real one-to-one personal interview sessions.

\section{Results and Discussion}

First, the emerging patterns related to the cultural bias components will be discussed: gathering information before travelling to the Erasmus target country, false beliefs about the target culture, foreigner students' information about Hungarian culture, positive and negative perceptions in the target country as well as overall impressions during the respondents' stay in their host countries. Next, the variables of affective attitude to the target language, culture, country and members of the target culture will be discussed.

\section{Cultural Bias}

A source of cultural bias can be the lack of information about the target culture, the country and its people. All of the participants regarded it as essential to collect detailed information about their destination prior to their Erasmus mobility by exploring and consulting various resources, mainly the Internet, guidebooks, newspapers, TV and friends. The fact that the participants found it crucial to gain knowledge about their destination during the preparation process for their Erasmus study and/or internship programme suggests that these students had an inner drive to be equipped and well-prepared for intercultural encounters outside their classrooms and native country.

Despite gathering information about their target culture the participant Erasmus students still had some unexpected experience. For example, Marian mentioned she was surprised that at her Italian host institution assessment is done on a 30-point-scale and 18 points means a pass and that the academic year is divided into three trimesters involving teaching on Saturdays. However, she emphasised that apart from these university customs, she did not experience any other strange differences between her home and the host country. The other five participants did not provide an example to this question, which suggests that during the forthcoming face-to-face interviews special attention must be paid to this item to be able to elicit more informative data.

All the participants seemed to agree that the foreign students they encountered with in Finland, Germany, Italy and Romania have certain but limited knowledge about Hungary and its culture. For instance, Dia found that the students she met in Italy had some information and experience regarding Budapest and that they had taken nice trips in Hungary and they emphasised that the 
food was really tasty. Furthermore, Vera mentioned that all of the Fins that she had met know about Hungary and they had learnt about the Hungarian language at school.

The participants' favourable affective attitudes towards the target language and culture were further enhanced by their positive perceptions in various fields of their everyday life during their stay in their target country. Marian conjured up her experience in Italy:

...successful bargain at the market-place, Hungarian evening, when we prepared with Hungarian food, music... art exhibitions, jazz concerts, Verdi's Rigoletto... a chocolate festival... A really sweet memory is when we got to know an Italian boy whose major is Hungarian and who can speak almost fluent Hungarian... and invited several Hungarian students for dinner to his family. Marian

Marian's account conveys that out-of-class face-to-face interpersonal encounters with members of the target country in their native context as wells as with students of various nationalities play a significant role in the development of positive experience. Dia reinforced this as she claimed that hanging out with Italian and Erasmus students in Italy during excursions, special evening programmes contributed to her positive perceptions. Zoe had absolutely similar experience while taking part in the Hamburg festival in Germany. However, it was also detected that along with positive perceptions certain negative ones also emerged. The students gave accounts of some negative experience which rooted in three main sources: 1) language-related inconveniences, 2) differing mentalities and 3) some practical problems (heating, food etc.). For example, Nora mentioned some misunderstanding because of her poor Italian in the beginning, or Roland expressed his disappointment at the cuisine in the host country.

Regarding the participants' overall impressions about the target country, it was pointed out that these students' opinion about the host country as well as about its culture and people did not change or solely to a minor extent. Zoe felt that the Germans she met during her Erasmus stay in the Western part of Germany were similar to the ones she had envisioned based on her previous knowledge about them. She emphasised that they are fairly helpful and considerate. Vera also pointed out that she had had much information about the Fins even before she travelled there. The only change is that she is even more intensively interested in Finland and Finnish culture. Marian has always been fascinated by the Italian lifestyle and what she emphasised is the importance of her first-hand real-life experience.

\section{Affective Attitudes}

Concerning affective attitudes, it has been found that prior to commencing their Erasmus study or internship the participants had already demonstrated a positive language-related attitude towards the language of the target country, where they wished to carry out their Erasmus programme. A typical pattern that emerged from the answers was that learning the target language and affection towards the culture and the natural environment of the target country went hand in hand in the case of these participants. For instance Dia, who spent six months in Italy, revealed that she had always been attracted by Italian culture and the Italian way of life and the dramatic Italian landscape also appealed to her. Marian, who spent an academic year in Italy, showed a slightly more complex pattern of motivations and attitudes for choosing an Italian higher educational institution as her Erasmus destination. She said that she had been learning Italian for several years as wells as that Italy, Italian mentality and people are deep in her heart, so it went without saying for her to choose this southern European destination. Vera staying in another corner of Europe, Finland had a 
very similar attitude and driving force to develop her Finnish language skills and immerse in Finnish culture and everyday life.

Based on the interview data, it can be concluded that all the participants can be characterised by positive target language related attitude along with positive attitudes towards the culture, the country and the speakers of the target language as well.

\section{Conclusions}

A 'quasi' semi-structured interview study was conducted with six Hungarian Erasmus students with a two-fold aim. First, this qualitative investigation was intended to be an exploration of these Erasmus students' patterns of the cultural biases and affective attitudes affected by the Erasmus student mobility programme. Second, this small scale research was carried out to pilot the interview protocol designed for a larger-scale interview study. The present investigation is considered quasi since the interview schedule was piloted through the written answers of the respondents without a personal face-to-face session with the students. During the procession of the data the emerging patterns of the students' cultural biases, affective attitudes and the effects of the Erasmus programme on these variables were highlighted. The students' answers yielded the following answers to the research questions.

\section{Research Question 1: What impacts does the LLP Erasmus student mobility programme have on cultural biases among students?}

It was detected that all of the respondents had collected information about the target culture in advance prior to their Erasmus programme and demonstrated an inner driving force to get acquainted with the target culture and country. Having equipped with information about the geography, everyday life etc. about their destination, they still reported on some of their false beliefs/information about the host culture; although to a very minor extent. However, it is crucial to mention that it did not turn out precisely to what extent they had had exposure to intercultural encounters and gained first hand intercultural experience and knowledge about the host country, its culture and people.

\section{Research Question 2: What effects does Erasmus student mobility have on the participants' affective attitudes?}

Basically all the six Erasmus students' positive affective attitudes were detected even prior to their visit to the target culture. These attitudes were based on their learning of the target language and mainly on their indirect intercultural contact with members of the target culture (via the Internet, books, friends etc.). During the Erasmus programmes all of the respondents perceived that their positive experiences abroad outnumbered the negative ones, which strengthened their affective attitudes towards the target country/culture and people.

\section{Research Question 3: To what extent can the pilot interview schedule elicit informative answers to the research questions?}

The piloted interview protocol yielded proper information to be able to study Erasmus students' affective attitudes; however, the construct of cultural bias needs a more specific conceptualization and the related interview items require some further elaboration. 
The present study has certain limitations and the most significant one is that the semistructured interview schedule was completed as an open-ended questionnaire by the respondents. Interpersonal interviews could have resulted in deeper, more specific answers to the questions and at the same time prompts could have been developed and tested. Still the collected written data provided by the six students can be regarded as useful in that the questions elicited the type of information that was needed only the depth was occasionally dissatisfactory. In the next phase of this research interpersonal one-to-one interviews will be conducted with the modified form of this interview schedule. Another limitation of the present investigation is the selection of the participants. That is, due to the technique of convenience sampling, it can be supposed that the Erasmus students who experienced positive intercultural encounters and had positive overall impressions about their stay in their host country were more motivated to volunteer for completing the interview questions. All in all, generalization cannot be drawn from this investigation, which was designed to be an explorative pilot study.

In sum, it can be claimed that the LLP Erasmus student mobility programme enhanced the participant students' openness towards the target foreign cultures as well as their positive affective attitudes. It was detected that despite the students' focus on the target culture before travelling to the host country, they still had limited knowledge about the target country on arrival. Therefore, the most principal pedagogical implication of the results is that various kinds of special intercultural training programmes are beneficial for Erasmus students both in the home and the host institutions' educational framework.

\section{References}

Allport, G. W. (1954): The nature of prejudice. Reading, MA: Addison-Wesley.

Brewer, M. B., \& Kramer, R. (1985): The psychology of intergroup attitudes and behaviour. In: Annual Review Psychology, 36, pp. 219-43.

Cohen, E. G. (1982): Expectation states and interracial interaction in school settings. In: Annual Review of Psychology, 8, pp. 209-35.

Cohen, E. G., \& Lotan, R. A. (1995): Producing equal-status interaction in the heterogeneous classroom. In: American Educational Research Journal, 32(1), pp. 99-120.

Van Dick, R., Wagner U., \& Pettigrew, T. F. (2004): Role of perceived importance in intergroup contact. In: Journal of Personality and Social Psychology, 87, pp. 211-227.

Dörnyei, Z. (2007): Research methods in applied linguistics: Quantitative, qualitative, and mixed methodologies. Oxford: Oxford Applied Linguistics.

Eller, A., \& Abrams, D. (2006): A people's entente cordiale? The role of implicit attitude in the relationship between English-French contact, levels of categorization and explicit intergroup attitudes. In: Current Research in Social Psychology, 11, pp. 92-110.

Nemetz-Robinson, G. L. (1985): Cross-cultural understanding. Processes and approaches for foreign language ESL and bilingual educators. London: Prentice Hall.

Pettigrew, T. F. (1986): The Intergroup Contact Hypothesis reconsidered. In: M. Hewstone, \& R. Brown (Eds.): Contact and Conflict in Intergroup Encounters. New York: Basil Blackwell, pp. 16995.

Pettigrew, T. F. (1998): Intergroup contact theory. Annual Review of Psychology, 49, pp. 65-85.

Stephan, W. G. (1987): The Contact Hypothesis in intergroup relations. In: C. Hendrick, (Ed.), Review of personality in social psychology. Newbury Park CA: SAGE Publications, pp. 13-40.

Scott, W. A. (1966): Measures of Cognitive Structure. In: Multivariate Behavioral Research, 1, pp. 391395.

Tajfel, H., \& Turner, J. (1979): An integrative theory of intergroup conflict. In: W. G. Austin, \& S. 
Worchel (Eds.): The social psychology of intergroup relations. California: Brooks \& Cole, pp. 33-47. Watson, G. (1947): Action for unity. New York: Harper.

Williams, R. M. (1947): The reduction of intergroup tensions. New York: Social Science Research Council.

Education and Training, Retrieved on 4 August 2014 from http://ec.europa.eu/education/tools/llp_en.htm

Council of Europe, Common European Framework of Reference for Languages: Learning, Teaching, Assessment (CEFR), Retrieved on 4 August 2014 from http://www.coe.int/t/dg4/linguistic/cadre1_en.asp

European Commission, Education and Training, Retrieved on 30 January 2013 from http://ec.europa.eu/education/erasmus/placement_en.htm

Merriam Webster on-line dictionary, Retrieved on 4 August, 2014 from http://www.merriamwebster.com/dictionary/bias

Tempus Közalapítvány, Retrieved on 30 January 2013 from http://www.tpf.hu/pages/content/index.php?page_id=578, European Commission

\section{About the Author}

Dr. Rita Szaszkó, Szent István University, Faculty of Applied Arts and Pedagogy/Jászberény (Hungary). Contact: Szaszko.Rita@abpk.szie.hu 